\title{
Staff Knowledge and Attitudes Towards COVID-19 New Biosafety Practices at a Brazilian Dental School
}

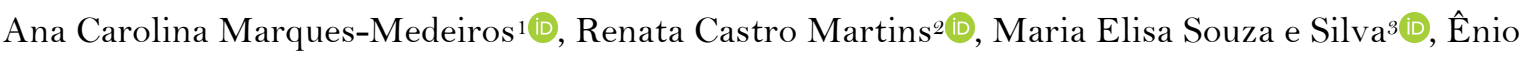

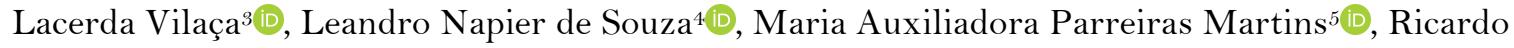 \\ Santiago Gomez ${ }^{(}$, Mauro Henrique Nogueira Guimarães de Abreu(i)
}

\footnotetext{
${ }^{1}$ Graduate Program in Dentistry, Federal University of Minas Gerais, Belo Horizonte, MG, Brazil.

${ }^{2}$ Department of Community and Preventive Dentistry, Federal University of Minas Gerais, Belo Horizonte, MG, Brazil.

${ }^{3}$ Department of Operative Dentistry, Federal University of Minas Gerais, Belo Horizonte, MG, Brazil.

${ }^{4}$ Department of Oral Surgery and Oral Pathology, Federal University of Minas Gerais, Belo Horizonte, MG, Brazil.

${ }^{5}$ Department of Pharmaceutical Products, Federal University of Minas Gerais, Belo Horizonte, MG, Brazil.
}

Correspondence: Mauro Henrique Nogueira Guimarães de Abreu, Avenida Antônio Carlos, 6627, Pampulha, Belo Horizonte, MG, Brazil. 31270901. E-mail: maurohenriqueabreu@gmail.com

Academic Editor: Alessandro Leite Cavalcanti

Received: 21 July 2021 / Review: 14 September 2021 / Accepted: 26 September 2021

How to cite: Marques-Medeiros AC, Martins RC, Silva MES, Vilaça EL, Souza LN, Martins MAP, et al. Staff knowledge and attitudes towards COVID-19 new biosafety practices at a Brazilian dental school. Pesqui Bras Odontopediatria Clín Integr. 2022; 22:e2 10139. https://doi.org/10.1590/pboci.2022.007

\begin{abstract}
Objective: To evaluate knowledge and attitudes towards biosafety recommendations during the COVID-19 pandemic at a Brazilian dental school. Material and Methods: A cross-sectional study was performed in 2020 with the clinical staff of a Brazilian dental school. The whole clinical staff was sent pre-tested selfadministered online questionnaires about knowledge and attitudes towards the recommendations for biosafety in dental settings in the context of the COVID-19 pandemic. Descriptive statistical analyses were carried out for proportion calculation. Results: Disposable head covering caps, isolation gowns, and gloves were the most frequently reported personal protective equipment (PPE). The rates ranged from $52.9 \%$ to $88.5 \%$ for N95 respirators, from $68.6 \%$ to $92.6 \%$ for face shields, from $47.4 \%$ to $67.5 \%$ for conventional eye protection shields, and $45.1 \%$ to $77.4 \%$ for eye protection with solid side shields. Chlorhexidine gluconate was the most frequent mouthwash indicated before clinical dental care. The percentage of agreement to provide clinical care to patients with suspected COVID-19 varied from $23.5 \%$ to $50.0 \%$. The percentage of respondents who agreed that bioaerosol-generating procedures should be avoided was higher than $74.5 \%$. Less than $50 \%$ knew the correct sequence for doffing of PPE. Conclusion: This study revealed important gaps in knowledge and attitudes towards prevention and control measures against infection in dental environments in the context of COVID-19, indicating the need for improvements.
\end{abstract}

Keywords: COVID-19; Education, Dental; Infection Control, Dental. 


\section{Introduction}

The explosive growth of COVID-19 infection worldwide has brought, in different countries, immediate and important impacts on healthcare, including dentistry. Dental treatment has shown potential risks of SARS-CoV-2 infection, both for professionals and patients, mainly because dental treatment involves several bioaerosol-generating procedures [1,2]. Accordingly, dentistry has been pointed out as one of the professions with the highest risk of exposure to COVID-19, requiring specific biosafety protocols and individual assessment of the patient's clinical status. Therefore, to break the chain of transmission, the entire dental staff should be aware of the pathways of disease dissemination, identifying suspected or confirmed cases and strictly following the recommendations for control of infection in dental settings, including teaching and research environments [3-6].

The new biosafety protocols in dentistry have undergone constant adjustments following the scientific evidence that has been published since the onset of the COVID-19 pandemic [7-9]. The changes suggested by regulatory health agencies and the board of professionals are important in the short, medium, and long term. However, there is still a lack of specific studies on the level of knowledge and attitudes of professionals and undergraduates to the new recommendations in dental care environments, leading to further possible gaps and deficiencies. Given this scenario, it is clear that there will be important changes in dental care guidelines, leaving the decision about the best logistic strategy to each health service, depending on the resources and guidance provided by the best scientific evidence.

Dental schools have already gone in that direction by implementing changes in teaching practices. Dental schools from several countries have introduced restrictions on elective dental care, implemented remote education, and established new protocols for infection control [5,10-12]. Looking at this scenario, there is an apparent need to adapt the dental school curriculum in the context of the COVID-19 pandemic and train the entire team in education and research techniques during the current health crisis $[5,10,13]$. These changes, however, must be accompanied by studies on their actual effectiveness, the impacts of their application, and the ability of the dental staff involved in the teaching-learning process and dental care to adhere to the new protocols. Understanding the knowledge and attitudes towards the clinical dental staff could be the first step. Hence, the aim of this study was to evaluate knowledge and attitudes towards biosafety recommendations during the COVID-19 pandemic at a Brazilian dental school.

\section{Material and Methods}

Study Design and Sample

A cross-sectional descriptive epidemiological study was conducted with the clinical staff at the Dental School of Universidade Federal de Minas Gerais before the return of dental treatment. We included all dental students enrolled in undergraduate $(n=560)$ and graduate $(n=246)$ courses offered by this Dental School, Faculty members $(n=117)$, and dental assistants $(n=58)$.

\section{Data Collection}

The questionnaires were sent from November to December 2020. A pre-tested self-administered online questionnaire was used for data collection. The first version of the questionnaire was evaluated by two experts in infection control practices in dental settings. After that, the pilot version of the questionnaire with the incorporated suggestions was applied to a group of 42 invited participants, consisting of students, faculty members, and dental assistants. After two weeks, a retest was applied. A new adaptation to the questionnaire 
was made, and another pilot study was carried out with a test and retest with five individuals. The Kappa coefficient was employed to assess the temporal stability of the questionnaire, which proved to be appropriate (Cohen Kappa>0.60). The final version of the questionnaire contained three sections. The first section of the questionnaire included demographic data. The second section had eight questions about different types of personal protective equipment (PPE) used in the dental setting. The third section consisted of knowledge about biosafety recommendations in dental settings. In that section, the respondents had to answer about their level of agreement using a Likert-type scale [14], with the format of a typical five-level: Strongly agree; Agree; Neither agree nor disagree; Disagree; Strongly disagree. In the latter case, eight statements about risk classification of clinical dental care, processing of health products, cleaning and disinfection of the workplace area and dental molds, disposal of sharp materials, emergency dental care to patients with suspected COVID19, dental care by professionals with suspected COVID-19, and aerosol-generating procedures. Two questions addressed apparel procedures. The questionnaire was entered into Google Forms and sent out to the participants by e-mail, social media, and instant messaging applications.

\section{Data Analysis}

To evaluate the level of knowledge and attitude towards the use of PPE, scores were constructed, ranging from 0 (no report of the use of any type of PPE) to 6 (when the respondent reported the use of all PPE). Data collected were tabulated and processed in Excel ${ }^{\circledR}$ spreadsheets, and, subsequently, descriptive statistics were performed using the SPSS software version 25 (IBM SPSS Statistics, Armonk, NY, USA). The SPSS license is available under and any requirement for permission for use.

\section{Ethical Clearance}

All the participants evaluated and electronically signed the consent form. The study was submitted to and approved by the UFMG Research Ethics Committee (CAAE: 31041720.3.0000.5 149).

\section{Results}

A total of 549 clinical staff members participated in the study. The response rate for undergraduate students was $67.9 \%(\mathrm{n}=380), 16.3 \%(\mathrm{n}=40)$ for graduate students, $66.7 \%(\mathrm{n}=78)$ for faculty members, and $91.1 \%(\mathrm{n}=51)$ for dental assistants. Demographic data on the participants are presented in Table 1.

Table 1. Frequency of demographic data on the dental school's clinical staff.

\begin{tabular}{lc}
\multicolumn{1}{c}{ Variables } & $\%$ \\
\hline Female Sex & 73.7 \\
Undergraduate student $(\mathrm{n}=380)$ & 92.5 \\
Graduate $(\mathrm{n}=40)$ & 52.6 \\
Faculty members $(\mathrm{n}=78)$ & 78.4 \\
Dental assistants $(\mathrm{n}=51)$ & Mean (Standard Deviation) \\
Age (years) & $23.2( \pm 2.8)$ \\
Undergraduate student $(\mathrm{n}=375)$ & $29.6( \pm 5.9)$ \\
Graduate $(\mathrm{n}=38)$ & $46.8( \pm 9.5)$ \\
Faculty members $(\mathrm{n}=76)$ & $46.2( \pm 10.3)$ \\
Dental assistants $(\mathrm{n}=51)$ & \\
\hline
\end{tabular}

Disposable head covering caps, isolation gowns, and gloves were the most frequently reported PPE. More than $70 \%$ of the respondents reported the use of surgical masks or N95-type respirators, except for 
dental assistants, whose use of respirators accounted for $52.9 \%$. The use of face shields exhibited low rates, especially among the dental assistants, ranging from $68.6 \%$ among dental assistants to $92.6 \%$ among undergraduate students. The use of conventional eye protection side shields ranged from $47.4 \%$ among faculty members to $67.5 \%$ among graduate students. The rate for eye protection shields with solid sides ranged from $45.1 \%$ among dental assistants to $77.4 \%$ among undergraduate students (Table 2 ).

Table 2. Frequency of the clinical staff's knowledge and attitudes towards the use of PPE recommended in the context of the COVID-19 pandemic at a dental school.

\begin{tabular}{|c|c|c|c|c|c|}
\hline Variables & Answer & $\begin{array}{c}\text { Undergraduate } \\
\text { Student }(\mathbf{n}=\mathbf{3 8 0}) \\
\%\end{array}$ & $\begin{array}{c}\text { Graduate } \\
\text { Student }(n=40) \\
\%\end{array}$ & $\begin{array}{c}\text { Faculty } \\
\text { Members }(\mathbf{n}=78) \\
\%\end{array}$ & $\begin{array}{c}\text { Dental Assistants } \\
\qquad(\mathbf{n}=\mathbf{5} 1) \\
\%\end{array}$ \\
\hline Use of & Yes & 99.2 & 97.5 & 100.0 & 90.2 \\
\hline disposable head & No & 0.5 & 0.0 & 0.0 & 9.8 \\
\hline covering caps & Don't want to inform & 0.3 & 2.5 & 0.0 & 0.0 \\
\hline Use of surgical & Yes & 86.1 & 82.5 & 76.9 & 76.5 \\
\hline mask & No & 11.3 & 17.5 & 23.1 & 19.6 \\
\hline & Don't want to inform & 2.6 & 0.0 & 0.0 & 3.9 \\
\hline Use of N95 & Yes & 82.1 & 77.5 & 88.5 & 52.9 \\
\hline respirator or & No & 9.7 & 17.5 & 9.0 & 39.2 \\
\hline similar PPE & Don't want to inform & 8.2 & 5.0 & 2.6 & 7.8 \\
\hline Use of isolation & Yes & 85.3 & 77.5 & 96.2 & 80.4 \\
\hline gown & No & 6.8 & 17.5 & 3.8 & 17.6 \\
\hline & Don't want to inform & 7.9 & 5.0 & 0.0 & 2.0 \\
\hline Use of gloves & Yes & 97.9 & 97.5 & 97.4 & 86.3 \\
\hline & No & 1.8 & 2.5 & 2.6 & 11.8 \\
\hline & Don't want to inform & 0.3 & 0.0 & 0.0 & 2.0 \\
\hline Use & Yes & 66.6 & 67.5 & 47.4 & 49.0 \\
\hline conventional eye & No & 28.9 & 30.0 & 51.3 & 45.1 \\
\hline $\begin{array}{l}\text { protection } \\
\text { shields }\end{array}$ & Don't want to inform & 4.5 & 2.5 & 1.3 & 5.9 \\
\hline Use of eye & Yes & 77.4 & 55.0 & 66.7 & 45.1 \\
\hline protection with & No & 15.5 & 40.0 & 32.1 & 51.0 \\
\hline solid side shields & Don't want to inform & 7.1 & 5.0 & 1.2 & 3.9 \\
\hline Use of face & Yes & 92.6 & 87.5 & 88.5 & 68.6 \\
\hline shield & No & 3.4 & 10.0 & 10.3 & 21.6 \\
\hline & Don't want to inform & 3.9 & 2.5 & 1.3 & 9.8 \\
\hline
\end{tabular}

The use of all PPE ranged from 27.5\% among dental assistants to $62.9 \%$ among undergraduate students (Table 3).

Table 3. Mean score of outcome measures of knowledge and attitudes of the clinical staff at a dental school towards the use of PPE recommended in the context of COVID-19.

\begin{tabular}{|c|c|c|c|}
\hline Clinical Staff & Score & $\mathbf{N}$ & $\%$ \\
\hline \multirow[t]{6}{*}{ Undergraduate Student } & 2.0 & 6 & 1.6 \\
\hline & 3.0 & 24 & 6.3 \\
\hline & 4.0 & 42 & 11.1 \\
\hline & 5.0 & 69 & 18.2 \\
\hline & 6.0 & 239 & 62.9 \\
\hline & Total & 380 & 100 \\
\hline \multirow[t]{6}{*}{ Graduate } & 2.0 & 4 & 10.0 \\
\hline & 3.0 & 1 & 2.5 \\
\hline & 4.0 & 5 & 12.5 \\
\hline & 5.0 & 14 & 35.0 \\
\hline & 6.0 & 16 & 40.0 \\
\hline & Total & 40 & 100.0 \\
\hline Faculty Member & 1.0 & 1 & 1.3 \\
\hline
\end{tabular}




\begin{tabular}{|c|c|c|c|}
\hline & 2.0 & 1 & 1.3 \\
\hline & 3.0 & 1 & 1.3 \\
\hline & 4.0 & 2 & 2.6 \\
\hline & 5.0 & 33 & 42.3 \\
\hline & 6.0 & 40 & 51.3 \\
\hline & Total & 78 & 100.0 \\
\hline \multirow[t]{8}{*}{ Dental Assistants } & 0.0 & 3 & 5.9 \\
\hline & 1.0 & 3 & 5.9 \\
\hline & 2.0 & 2 & 3.9 \\
\hline & 3.0 & 5 & 9.8 \\
\hline & 4.0 & 10 & 19.6 \\
\hline & 5.0 & 14 & 27.5 \\
\hline & 6.0 & 14 & 27.5 \\
\hline & Total & 51 & 100.0 \\
\hline
\end{tabular}

The respondents could indicate more than one type of mouthwash before clinical dental care. Chlorhexidine gluconate was the most frequently cited mouthwash (Table 4).

Table 4. Assessment of knowledge and attitudes of the clinical staff at a dental school towards the use of mouthwashes recommended in the context of COVID-19.

\begin{tabular}{lcccc}
\hline Mouthwash & $\begin{array}{c}\text { Undergraduate } \\
\text { Student }(\mathbf{n = 3 8 0})\end{array}$ & $\begin{array}{c}\text { Graduate Student } \\
(\mathbf{n = 4 0 )}\end{array}$ & $\begin{array}{c}\text { Faculty Member } \\
(\mathbf{n = 7 8}) \\
\%\end{array}$ & $\begin{array}{c}\text { Dental Assistants } \\
(\mathbf{n = 5 1}) \\
\%\end{array}$ \\
\hline Chlorhexidine Gluconate & 72.1 & 85.0 & 79.5 & 64.7 \\
Hydrogen Peroxide & 14.7 & 25.0 & 28.2 & 7.8 \\
Povidone-Iodine & 3.2 & 0.0 & 3.8 & 2.0 \\
Cetylpyridinium Chloride & 5.0 & 0.0 & 9.0 & 11.8 \\
Essential Oils & 1.6 & 0.0 & 1.3 & 0.0 \\
Sodium Fluoride & 0.0 & 0.0 & 0.0 & 0.0 \\
0.9\% Saline & 0.5 & 0.0 & 0.0 & 0.0 \\
\hline
\end{tabular}

Most of the clinical staff believe that clinical dental care presents a very high risk for SARS-CoV-2 transmission. High percentages of agreement were obtained for sterilization, disinfection, and management of sharp materials among all clinical staff members. The percentage of participants who agreed to provide clinical care to patients with suspected COVID-19, even in the case of a dental emergency, varied from $23.5 \%$ among dental assistants to $50.0 \%$ among undergraduate students. The percentage of respondents who agreed that bioaerosol-generating procedures should be avoided ranged from $74.5 \%$ among dental assistants to $88.5 \%$ among faculty members. The rate of correct answers for the proper sequence for donning of PPE ranged from $62.7 \%$ among dental assistants to $85.0 \%$ among undergraduate students. Less than $50 \%$ knew the correct sequence for doffing of PPE (Table 5).

Table 5. Assessment of knowledge and attitudes towards biosafety in the context of the COVID-19 pandemic at a dental school, Brazil, 2020.

\begin{tabular}{|c|c|c|c|c|c|}
\hline \multirow[t]{2}{*}{ Variables } & \multirow[t]{2}{*}{ Answer } & \multirow{2}{*}{$\begin{array}{l}\text { Undergraduate } \\
\text { Student }(n=380)\end{array}$} & \multicolumn{3}{|c|}{ Graduate Student Faculty Members Dental Assistants } \\
\hline & & & $(n=40)$ & $(n=78)$ & $(n=51)$ \\
\hline \multirow{6}{*}{$\begin{array}{l}\text { "Currently, clinical dental } \\
\text { care presents a very high } \\
\text { risk for SARS-CoV-2 } \\
\text { transmission." }\end{array}$} & Strongly agree & 52.4 & 35.0 & 53.8 & 72.5 \\
\hline & Agree & 32.6 & 42.5 & 38.5 & 21.6 \\
\hline & Neither agree nor disagree & 3.7 & 2.5 & 1.3 & 0.0 \\
\hline & Disagree & 8.2 & 15.0 & 3.8 & 3.9 \\
\hline & Strongly disagree & 1.6 & 5.0 & 2.6 & 0.0 \\
\hline & I don't know/I'm torn & 1.6 & 0.0 & 0.0 & 2.0 \\
\hline \multirow{4}{*}{$\begin{array}{l}\text { "Any clinical, restorative, } \\
\text { surgical, periodontal, and } \\
\text { endodontic instrument } \\
\text { must be sterilized prior to }\end{array}$} & Strongly agree & 98.7 & 100.0 & 98.7 & 98.0 \\
\hline & Agree & 0.8 & 0.0 & 0.0 & 0.0 \\
\hline & Neither agree nor disagree & 0.0 & 0.0 & 0.0 & 0.0 \\
\hline & Disagree & 0.0 & 0.0 & 0.0 & 0.0 \\
\hline
\end{tabular}




\begin{tabular}{|c|c|c|c|c|c|}
\hline \multirow[t]{2}{*}{ service." } & Strongly disagree & 0.0 & 0.0 & 1.3 & 0.0 \\
\hline & I don't know/I'm torn & 0.5 & 0.0 & 0.0 & 2.0 \\
\hline \multirow{5}{*}{$\begin{array}{l}\text { "The dental chair, its } \\
\text { peripheral equipment, and } \\
\text { fixed surfaces must be } \\
\text { cleaned and disinfected, } \\
\text { adopting the protocols }\end{array}$} & Strongly agree & 98.7 & 100.0 & 100.0 & 98.0 \\
\hline & Agree & 0.8 & 0.0 & 0.0 & 0.0 \\
\hline & Neither agree nor disagree & 0.3 & 0.0 & 0.0 & 0.0 \\
\hline & Disagree & 0.0 & 0.0 & 0.0 & 0.0 \\
\hline & Strongly disagree & 0.0 & 0.0 & 0.0 & 0.0 \\
\hline \multicolumn{2}{|l|}{$\begin{array}{l}\text { approved by the } \\
\text { institution." }\end{array}$} & 0.3 & 0.0 & 0.0 & 2.0 \\
\hline \multirow{6}{*}{$\begin{array}{l}\text { "The study model or } \\
\text { working model should } \\
\text { always be disinfected." }\end{array}$} & Strongly agree & 92.9 & 95.0 & 96.2 & 88.2 \\
\hline & Agree & 3.2 & 2.5 & 0.0 & 2.0 \\
\hline & Neither agree nor disagree & 0.3 & 0.0 & 0.0 & 0.0 \\
\hline & Disagree & 0.8 & 0.0 & 1.3 & 0.0 \\
\hline & Strongly disagree & 0.3 & 0.0 & 1.3 & 2.0 \\
\hline & I don't know/I'm torn & 2.6 & 2.5 & 1.3 & 7.8 \\
\hline \multirow{6}{*}{$\begin{array}{l}\text { "Every and } \quad \text { each } \\
\text { disposable sharp material } \\
\text { should always be disposed } \\
\text { of in a specific rigid } \\
\text { container." }\end{array}$} & Strongly agree & 98.7 & 100.0 & 100.0 & 92.2 \\
\hline & Agree & 0.3 & 0.0 & 0.0 & 5.9 \\
\hline & Neither agree nor disagree & 0.0 & 0.0 & 0.0 & 0.0 \\
\hline & Disagree & 0.0 & 0.0 & 0.0 & 0.0 \\
\hline & Strongly disagree & 0.3 & 0.0 & 0.0 & 0.0 \\
\hline & I don't know/I'm torn & 0.8 & 0.0 & 0.0 & 2.0 \\
\hline \multirow{6}{*}{$\begin{array}{l}\text { "A patient with fever, } \\
\text { fatigue, cough, and } \\
\text { headache may receive } \\
\text { emergency dental care." }\end{array}$} & Strongly agree & 17.6 & 25.0 & 15.4 & 13.7 \\
\hline & Agree & 22.4 & 25.0 & 26.9 & 9.8 \\
\hline & Neither agree nor disagree & 6.1 & 2.5 & 2.6 & 3.9 \\
\hline & Disagree & 14.5 & 15.0 & 23.1 & 15.7 \\
\hline & Strongly disagree & 24.2 & 30.0 & 26.9 & 45.1 \\
\hline & I don't know/I'm torn & 15.3 & 2.5 & 5.1 & 11.8 \\
\hline \multirow{6}{*}{$\begin{array}{l}\text { "A professional with fever, } \\
\text { fatigue, cough, and } \\
\text { headache can perform } \\
\text { dental care." }\end{array}$} & Strongly agree & 1.1 & 0.0 & 1.3 & 0.0 \\
\hline & Agree & 0.8 & 2.5 & 1.3 & 11.8 \\
\hline & Neither agree nor disagree & 0.8 & 0.0 & 0.0 & 0.0 \\
\hline & Disagree & 6.8 & 5.0 & 1.3 & 0.0 \\
\hline & Strongly disagree & 89.7 & 92.5 & 94.9 & 82.4 \\
\hline & I don't know/I'm torn & 0.8 & 0.0 & 1.3 & 5.9 \\
\hline \multirow{6}{*}{$\begin{array}{l}\text { "Aerosol-generating } \\
\text { dental procedures should } \\
\text { be avoided." }\end{array}$} & Strongly agree & 42.6 & 50.0 & 57.7 & 56.9 \\
\hline & Agree & 33.7 & 32.5 & 30.8 & 17.6 \\
\hline & Neither agree nor disagree & 7.6 & 10.0 & 1.3 & 3.9 \\
\hline & Disagree & 6.3 & 7.5 & 6.4 & 9.8 \\
\hline & Strongly disagree & 3.7 & 0.0 & 3.8 & 0.0 \\
\hline & I don't know/I'm torn & 6.1 & 0.0 & 0.0 & 11.8 \\
\hline \multirow{2}{*}{$\begin{array}{l}\text { Sequence recommended } \\
\text { for donning of PPE }\end{array}$} & Correct & 73.1 & 85.0 & 78.2 & 62.7 \\
\hline & Incorrect & 26.3 & 15.0 & 21.8 & 37.3 \\
\hline \multirow{2}{*}{$\begin{array}{l}\text { Sequence recommended } \\
\text { for doffing of PPE }\end{array}$} & Correct & 47.6 & 47.5 & 41.0 & 47.1 \\
\hline & Incorrect & 52.4 & 52.5 & 59.0 & 52.9 \\
\hline
\end{tabular}

\section{Discussion}

The knowledge and attitudes of the dental clinic staff could be considered invaluable resources to ensure a safety dental treatment in teaching institutions. In this study, we evaluated knowledge and attitudes on the new biosafety recommendations in the context of the COVID-19 pandemic. Furthermore, as demonstrated by the findings, these knowledge and attitudes of the evaluated clinical staff still need to be improved.

There was a possible lack of knowledge for indicating the type of mask suitable for clinical dental care, with similar rates for both surgical mask and N95 respirator. Low percentages were also obtained for the use of conventional goggles and eye protection with solid side shields. Among dental assistants, the percentage of face shield use was notably low. Regions with moderate to substantial COVID-19 community transmission are those which mostly require biosafety measures. Breaking the transmission chain requires preventive actions based on the transmission of infectious diseases and local epidemiological conditions [8]. Thus, the correct choice of PPE is quite relevant for the safety of both the dental team and the patient. The responses about the type of mask to be used in patient care at dental clinics are a cause for concern. In this type of care in the dental 
setting, aerosol generation may occur, and then the use of filtering facepiece respirators is recommended (i.e., N95 or FFP2 or FFP3 equivalent or standard), taking into account that a surgical mask does not provide respiratory protection $[7,8]$. With the aforementioned, a possible lack of awareness or lack of knowledge about the risks of transmission of SARS-CoV-2 by aerosols in these environments could be considered. Therefore, a possible lack of awareness or lack of knowledge about the risks of SARS-CoV-2 transmission by aerosols in these environments could be considered. Another worrying finding is the low rate for the use of goggles. Although the use of both goggles and face shields has not been strictly recommended, the Centers for Disease Control and Prevention (CDC) [8] warns about the use of universal eye protection and that equipment with spaces between eyeglasses and the face probably does not protect the eyes against all possible splashes, another mode of transmission of COVID-19. Hence, it is advisable to use goggles associated with a face shield while providing dental care. Such worrying percentages were evidenced by the low rate of use of all PPE. A previous study has described similarly low percentages for the use of goggles (37.1\%) and pff3/N95 respirators (11.5\%) [15]. Another study found a high percentage (85\%) of N95 respirator use, mainly for the treatment of COVID19 suspected cases [16]. In another study, respondents considered that universal precautions alone are ineffective in preventing the transmission of COVID-19 [17]. Failure to use the recommended PPE and its incorrect use can compromise the breakdown of pathogen transmission, increasing the risk of contamination of the whole dental team, as well as of patients. Some of the challenges in following the recommendations for the use of all PPE are discomfort and fatigue caused by overtightened masks, foggy goggles, headaches, and difficulty breathing, so increasing the adherence to the use of PPE is not an easy task. In addition, the correct use of PPE involves training implemented in advance, which does not occur in many health institutions $[18,19]$.

Our findings revealed that most participants indicated the use of chlorhexidine gluconate prior to dental care, unlike other studies [13,15]. Considering the possibility of COVID-19 transmission both by asymptomatic and symptomatic patients, there is also an indication for mouthwashes with oral antiseptics to reduce the salivary viral load in pre-dental care as a strategy to prevent the risk of cross-infection [2,20,21]. Since some mouthwashes eventually may have a microbial-reducing effect, the CDC recommends the use of products such as cetylpyridinium chloride, povidone-iodine, essential oils, or chlorhexidine gluconate, although the efficacy and safety of these rinses in COVID-19-positive patients have not been well established in the scientific literature [2,8]. These products are commonly used to control dental plaque, but not all of them have shown efficacy in reducing viral and bacterial loads; moreover, they may also be associated with adverse effects [22]. While some protocols indicate the use of hydrogen peroxide, as SARS-CoV-2 is vulnerable to the oxidative effect [23,24], there is still no scientific evidence that supports its effectiveness in any virus-reducing effect; hence, these dental protocols should be reviewed [23]. A systematic review identified currently available evidence that undiluted $1 \%$ povidone-iodine and $7 \%$ povidone-iodine diluted 1:30 may have the most effective antimicrobial activity against coronaviruses, albeit, the authors emphasized the need for further researches on such products once there are still only two in vitro studies available in the scientific literature [22].

The clinical staff's knowledge may be considered mostly adequate for sterilization of the dental instruments, disinfection of dental chairs and molds, and management of disposable sharp materials. These procedures did not change during the pandemic, and the respondents' previous knowledge could explain the high rate of correct answers. By contrast, when we analyzed the new biosafety practices during the COVID-19 pandemic, the rate of correct answers decreased. The increased risk of SARS-CoV-2 transmission during dental care is not considered by the overwhelming majority of the clinical staff members, especially by students. 
Another relevant fact was that a high percentage of respondents reported disagreement over the need to avoid aerosol-generating procedures, which corroborates a possible lack of awareness or lack of concern about the transmission of COVID-19 by aerosols. This type of knowledge showed variability in the dental literature [2527]. Dental practice commonly includes the use of ultrasonic scalers, high-speed handpieces, air-water syringes, and procedures that generate droplets and aerosols. These particles combined with body fluids, such as blood and saliva, generate bioaerosols that may be contaminated by more than 30 pathogenic microorganisms, in addition to SARS-CoV-2 [25,27,28]. There is also evidence that the risk of SARS-CoV-2 transmission was higher than that of other viruses from the same family, such as SARS-CoV-1 and MERS [6,28-30].

In the statement about a patient with fever, fatigue, cough, and headache, many participants disagreed that those patients could receive emergency dental care. As for the level of agreement on whether professionals with the same signs and symptoms could provide patient care, most disagreed with the statement. Although it is not explicit in the statements that the patients are identified as suspected cases, the refusal to offer care suggests that participants know how to recognize signs and symptoms suggestive of COVID-19. However, the current recommendation is that patients with suspected and confirmed COVID-19 should wait to receive elective dental care, but they can receive assistance in cases of urgent or emergency dental care, provided that the attending dentist takes additional high-level precautions [8]. The disagreement over the provision of emergency care to suspected cases may be due to a lack of information about the release for dental care in these cases or even a fear of contamination during care, as evidenced by previous studies. A considerable percentage has refused recently to attend to patients from countries with a high incidence of COVID-19, avoided attending to suspected cases, was afraid of infecting themselves or relatives or close friends, and advised students to avoid this type of care [13,15,25,31-33].

A critical part of the correct use of PPE and selection of the appropriate type of PPE rests with the donning and doffing of this equipment, especially when the nature of the procedure involves the generation of aerosols, for which the standard precaution is not sufficient to prevent self-contamination by COVID-19 [34]. The sequence recommended by the CDC can reduce the risk of contamination when compared to no recommendation, and the suggested order is similar to that of other important institutions such as the American Dental Association, the European Centre for Disease Prevention and Control, and the Brazilian National Health Surveillance Agency [7,8,34-36]. This order was used to assess the level of knowledge of the participants; however, it should be noted that several health agencies and professionals made their own recommendations since there were no dental protocols prior to the pandemic for the use of PPE [34]. A high percentage did not opt for the recommended sequence for PPE donning or doffing. Between these two procedures, the latter one presented the lowest percentage of correct answers and was the most critical for selfcontamination of health professionals and, therefore, the one that causes more concern $[34,36]$.

The general recommendations for COVID-19 prevention and control involve measures for the adequacy of the physical structure of dental settings, administrative control, and the use of appropriate precautions such as PPE [8]. The ultimate and penultimate measures depend on the professionals' knowledge and attitudes, and they are the most critical and, therefore, they should be constantly evaluated and worked on [37-40]. Training in biosafety in the context of COVID-19, focusing on the weaknesses presented here, has become of great relevance for the safe resumption of face-to-face activities. The current pandemic has shown how fragile clinical dental training is [11,13,25]. Therefore, the gaps demonstrated by the study serve to support institutional training for the entire team involved in dental care. It is necessary to point out that dental 
assistants were the group with the poorest knowledge and worse attitudes in this study, as previously reported in the literature [41]. This group should also participate in the biosafety continuing training and support to fill these gaps.

This study has some limitations that should be addressed. The research involved a specific population, not allowing generalizations about other dental care environments in Brazil and other countries. It has a crosssectional design, which does not allow assessing causality. Moreover, the instrument was not formally validated, taking into account the absence of a validated instrument in Brazilian Portuguese and the lack of time for a complete validation process of a new questionnaire. However, the research findings provide a general overview of the need for constant evaluation and training of dental teams. These findings may contribute to the development of a new work process in the dental field and to the adoption of educational measures to fill some teaching gaps.

\section{Conclusion}

This study showed important gaps that should be filled by the whole dental team, indicating that knowledge and attitudes towards prevention and control measures against infection in dental clinics, in accordance with the most recent recommendations, need to be improved. The findings of greatest concern were about the choice of appropriate PPE and the reduction of aerosol generation during dental treatment. In addition, professionals could be afraid of providing care for suspected cases of COVID-19 and with emergency status. Therefore, besides allowing easier access of the main health agencies to national and international protocols, it is highly recommended that educational institutions constantly assess the level of knowledge and attitudes to the new biosafety practices recommended in the context of COVID-19 for a safe environment for patients and dentists and quality academic education.

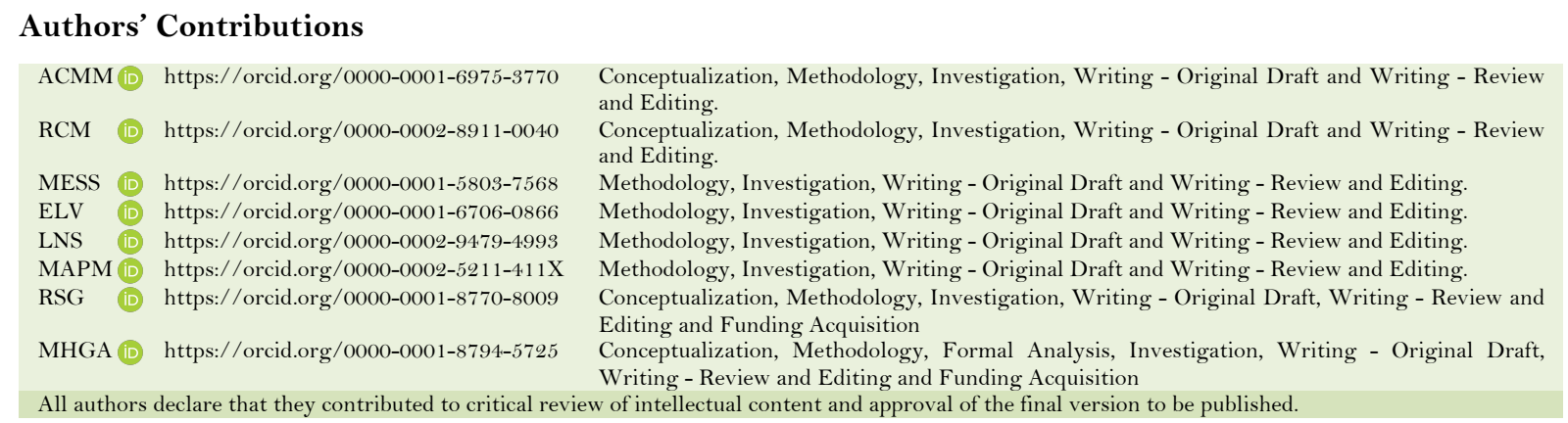

\section{Financial Support}

None.

\section{Conflict of Interest}

The authors declare no conflicts of interest.

\section{Data Availability}

The data used to support the findings of this study can be made available upon request to the corresponding author.

\section{References}

[1] Sabino-Silva R, Carolina A, Jardim G, Siqueira WL. Coronavirus COVID-19 impacts to dentistry and potential salivary diagnosis. Clin Oral Investig 2020; 24(4):1619-21. https://doi.org/10.1007/s00784-020-03248-x 
[2] Spagnuolo G, De Vito D, Rengo S, Tatullo M. COVID-19 outbreak: an overview on dentistry. Int J Environ Res Public Health 2020; 17(6):3-5. https://doi.org/10.3390/ijerph 17062094

[3] Checchi V, Bellini P, Bencivenni D, Consolo U. COVID-19 Dentistry-related aspects: a literature overview. Int Dent J 2020; 71(1):21-6. https://doi.org/10.1111/idj.12601

[4] Fallahi HR, Keyhan SO, Zandian D, Kim S-G, Cheshmi B. Being a front-line dentist during the Covid-19 pandemic: a literature review. Maxillofac Plast Reconstr Surg 2020; 42(1):12. https://doi.org/10.1186/s40902-020-00256-5

[5] Wu DT, Wu KY, Nguyen TT, Tran SD. The impact of COVID-19 on dental education in North America - Where do we go next? Eur J Dent Educ 2020; 24(4):825-7. https://doi.org/10.1111/eje.12561

[6] Villani FA, Aiuto R, Paglia L, Re D. Covid-19 and dentistry: Prevention in dental practice: a literature review. Int J Environ Res Public Health 2020; 17(12):1-12. https://doi.org/10.3390/ijerph 17124609

[7] Brasil. Agência Nacional de Vigilância Sanitária. Nota técnica GVIMS/GGTES/ ANVISA no 04/2020 atualizada em 25.02.2021. Orientações para serviços de saúde: Medidas de prevenção e controle que devem ser adotadas durante a assistência aos casos suspeitos ou confirmados pelo novo coronavírus (SARSCoV-2). 2020. Available from: http://portal.anvisa.gov.br/documents/33852/271858/Nota+Técnica+n+04-2020+GVIMS-GGTESANVISA/ab598660-3de4-4f14-8e6fb9341c196b28. [Accessed on February 26, 2021]. [In Portuguese].

[8] Centers for Disesase Control and Prevention. Guidance for Dental Settings. Interim Infection Prevention and Control Guidance for Dental Settings During the Coronavirus Disease 2019 (COVID-19) Pandemic. 2020. Available from: https://www.cdc.gov/coronavirus/2019-ncov/hcp/dental-settings.html. [Accessed on December 4, 2020].

[9] World Health Organization. WHO Director-General's statement on IHR Emergency Committee on Novel Coronavirus (2019-nCoV) [Internet]. WHO. 2020. Available from: https://www.who.int/directorgeneral/speeches/detail/who-director-general-s-statement-on-ihr-emergency-committee-on-novel-coronavirus(2019-ncov). [Accessed on December 4, 2020].

[10] Elangovan S, Mahrous A, Marchini L. Disruptions during a pandemic: gaps identified and lessons learned. J Dent Educ 2020; 84(11):1270-4. https://doi.org/10.1002/jdd.12236

[11] Quinn B, Field J, Gorter R, Akota I, Manzanares MC, Paganelli C, et al. COVID-19: The immediate response of European academic dental institutions and future implications for dental education. Eur J Dent Educ 2020; 24(4):8114. https://doi.org/10.1111/eje.12542

[12] Sukumar S, Dracopoulos SA, Martin FE. Dental education in the time of SARS-CoV-2. Eur J Dent Educ 2021; 25(2):325-31. https://doi.org/10.1111/eje.12608

[13] Jum'ah AA, Elsalem L, Loch C, Schwass D, Brunton PA. Perception of health and educational risks amongst dental students and educators in the era of COVID-19. Eur J Dent Educ 2021; 25(3):506-15. https://doi.org/10.1111/eje.12626

[14] Landis R., Koch G. An application of hierarchical kappa-type statistics in the assessment of majority agreement among multiple observers. Biometrics 1977; 33(2):363-74. https://doi.org/10.2307/2529786

[15] Ataş O, Yildirim TT. Evaluation of knowledge, attitudes, and clinical education of dental students about COVID-19 pandemic. PeerJ 2020; 8:e9575. https://doi.org/10.7717/peerj.9575

[16] Arora S, Saquib SA, Attar N, Pimpale S, Zafar KS, Saluja P, et al. Evaluation of knowledge and preparedness among indian dentists during the current Covid-19 pandemic: a cross-sectional study. J Multidiscip Healthc 2020; 13:841-54. https://doi.org/10.2147/JMDH.S268891

[17] de Abreu MHNG, Lopes-Terra MC, Braz LF, Rímulo AL, Paiva SM, Pordeus IA. Attitudes and behavior of dental students concerning infection control rules: a study with a10-year interval. Braz Dent J 2009; 20(3):221-5. https://doi.org/10.1590/So 103-64402009000300009

[18] Hoernke K, Djellouli N, Andrews L, Lewis-Jackson S, Manby L, Martin S, et al. Frontline healthcare workers' experiences with personal protective equipment during the COVID-19 pandemic in the UK: a rapid qualitative appraisal. BMJ Open 202 1; 11(1):e046199. https://doi.org/10.1136/bmjopen-2020-046199

[19] Houghton C, Meskell P, Delaney H, Smalle M, Glenton C, Booth A, et al. Barriers and facilitators to healthcare workers' adherence with infection prevention and control (IPC) guidelines for respiratory infectious diseases: a rapid qualitative evidence synthesis (Review). Cochrane Database Syst Rev 2020; (4):CDo13582. https://doi.org/10.1002/14651858.CD013582

[20] Meng L, Hua F, Bian Z. Coronavirus Disease 2019 (COVID-19): Emerging and future challenges for dental and oral medicine. J Dent Res 2020; 99(5):481-7. https://doi.org/10.1177/0022034520914246

[21] Peng X, Xu X, Li Y, Cheng L, Zhou X, Ren B. Transmission routes of 2019-nCoV and controls in dental practice. Int J Oral Sci 2020; 12(1):1-6. https://doi.org/10.1038/s41368-020-0075-9

[22] Cavalcante-Leão B, de Araujo C, Basso I, Schroder A, Guariza-Filho O, Ravazzi G, et al. Is there scientific evidence of the mouthwashes effectiveness in reducing viral load in Covid-19? a systematic review. J Clin Exp Dent 2021; 13(2):e179-89. https://doi.org/10.4317/jced.57406

[23] Ortega. K.L., Rech BO, Haje GLCE, Gallo CB, Pérez-Sayáns M, Braz-Silva PH. Do hydrogen peroxide mouthwashes have a virucidal effect? a systematic review. J Hosp Infect 2020; 106(4):657-62. https://doi.org/10.1016/j.jhin.2020.10.003 
[24] Vergara-Buenaventura A, Castro-Ruiz C. Use of mouthwashes against COVID-19 in dentistry. Br Jounal Oral Maxillofac Surg 2020; 58(8):924-7. https://doi.org/10.1016/j.bjoms.2020.08.016

[25] Loch C, Kuan IBJ, Elsalem L, Schwass D, Brunton PA, Jum'ah A. COVID-19 and dental clinical practice: Students and clinical staff perceptions of health risks and educational impact. J Dent Educ 2021; 85(1):44-52. https://doi.org/10.1002/jdd.12402

[26] Umeizudike KA, Isiekwe IG, Fadeju AD, Akinboboye BO, Aladenika ET. Nigerian undergraduate dental students' knowledge, perception, and attitude to COVID-19 and infection control practices. J Dent Educ 2021; 85(2):187-96. https://doi.org/10.1002/jdd.12423

[27] Zemouri C, De Soet H, Crielaard W, Laheij A. A scoping review on bio-Aerosols in healthcare \& the dental environment. PLoS One 2017; 12(5):1-26. https://doi.org/10.1371/journal.pone.0178007

[28] Ge Z, Yang L, Xia J, Fu X, Zhang Y. Possible aerosol transmission of COVID-19 and special precautions in dentistry. 2020; 21 (5):361-8. https://doi.org/10.1631/jzus.B2010010

[29] World Health Organization. Transmission of SARS-CoV-2: implications for infection prevention precautions Available from: https://www.who.int/publications/i/item/modes-of-transmission-of-virus-causing-covid-19implications-for-ipc-precaution-recommendations. [Accessed on December 4, 2020].

[30] Gandolfi MG, Zamparini F, Spinelli A, Sambri V, Prati C. Risks of aerosol contamination in dental procedures during the second wave of COVID-19 - experience and proposals of innovative IPC in dental practice. Int J Environ Res Public Health 2020; 17(23):1-12. https://doi.org/10.3390/ijerph17238954

[31] Chaudhary FA, Ahmad B, Ahmad P, Khalid MD, Butt DQ, Khan SQ. Concerns, perceived impact, and preparedness of oral healthcare workers in their working environment during COVID-19 pandemic. J Occup Health 2020; 62(1):17. https://doi.org/10.1002/1348-9585.12168

[32] Khader Y, Al Nsour M, Al-Batayneh OB, Saadeh R, Bashier H, Alfaqih M, et al. Dentists' awareness, perception, and attitude regarding COVID-19 and infection control: cross-sectional study among Jordanian dentists. JMIR Public Heal Surveill 2020; 6(2):1-11. https://doi.org/10.2196/18798

[33] Mustafa RM, Alshali RZ, Bukhary DM. Dentists' knowledge, attitudes, and awareness of infection control measures during COVID-19 outbreak: A cross-sectional study in Saudi Arabia. Int J Environ Res Public Health 2020; 17(23):114. https://doi.org/10.3390/ijerph 17239016

[34] Hegde S. Which type of personal protective equipment (PPE) and which method of donning or doffing PPE carries the least risk of infection for healthcare workers? Evid Based Dent 2020; 21(2):74-6. https://doi.org/10.1038/s41432-020-0097-3

[35] European Center for Disease Prevention and Control. Guidance for wearing and removing personal protective equipment in healthcare settings for the care of patients with suspected or confirmed COVID-19. 2020. Available from: https://www.ecdc.europa.eu/sites/default/files/documents/COVID-19-guidance-wearing-and-removingpersonal-protective-equipment-healthcare-settings-updated.pdf. [Accessed on December 4, 2020].

[36] Verbeek JH, Rajamaki B, Ijaz S, Sauni R, Toomey E, Blackwood B, et al. Personal protective equipment for preventing highly infectious diseases due to exposure to contaminated body fluids in healthcare staff. Emergencias 2021; 33(1):59-61. https://doi.org/10.1002/14651858.CD011621.pub4

[37] Ahmed MA, Jouhar R, Adnan S, Ahmed N, Ghazal T, Adanir N. Evaluation of Patient's Knowledge, Attitude, and Practice of Cross-Infection Control in Dentistry during COVID-19 Pandemic. Eur J Dent 2020; 14(Suppl 1):S1-S6. https://doi.org/10.1055/s-0040-1721295

[38] Ahmed N, Shakoor M, Vohra F, Abduljabbar T, Mariam Q, Rehman MA. Knowledge, awareness and practice of health care professionals amid sars-cov-2, corona virus disease outbreak. Pakistan J Med Sci 2020; 36(COVID19S4):S49-S56. https://doi.org/10.12669/pjms.36.COVID19-S4.2704

[39] Duruk G, Gumusboga ZŞ, ÇolaK C. Investigation of Turkish dentists' clinical attitudes and behaviors towards the COVID-19 pandemic: a survey study. Braz Oral Res 2020; 34:e054.

https://doi.org/10.1590/1807-3107bor-2020.vol34.0054

[40] Singh Gambhir R, Singh Dhaliwal J, Aggarwal A, Anand S, Anand V, Kaur Bhangu A. Covid-19: a survey on knowledge, awareness and hygiene practices among dental health professionals in an Indian scenario. Rocz Panstw Zakl Hig 2020; 71(2):223-9. https://doi.org/10.32394/rpzh.2020.0115

[41] Qudeimat MA, Farrah RY, Owais AI. Infection control knowledge and practices among dentists and dental nurses at a Jordanian university teaching center. Am J Infect Control 2006; 34(4):218-22. https://doi.org/10.1016/j.ajic.2005.06.012 